\title{
'Refugees Not Welcome Here': State, Church and Civil Society Responses to the Refugee Crisis in Poland
}

\author{
Kasia Narkowicz ${ }^{1}$ \\ Published online: 22 May 2018 \\ (C) The Author(s) 2018
}

\begin{abstract}
The Polish response to the crisis that escalated across Europe in 2015, banning refugees from crossing its borders, has been one of the least welcoming in Europe. Poland has been reprimanded by the EU for its lack of solidarity with other countries that accepted refugees. The government's response was that it does indeed welcome refugees as long as they are not Muslims, since letting Muslim refugees in would be a security risk. The figure of the Muslim terrorist posing as a refugee has become a key trope through which xenophobic nationalist politics have been employed. In this sense, Poland can be seen to be drawing particular inspiration from the Eurosceptic politics of Orbán's Hungary while also reflecting a broader European trend towards Islamophobia in countries such as France, Germany, Sweden or the UK. This article maps responses to refugees from key public actors. It focuses on how three key players in the Polish public sphere - the Catholic Church, the State and civil society actorsresponded to the looming perspective of welcoming refugees to Poland. The paper argues that the Polish response to the so-called refugee crisis should be analysed as subtext to a broader political change in the country towards nationalism that has as its goal to push out all foreign 'invasion'. Mobilised within this are new and old manifestations of racism, suggesting that Poland's long history of racial Othering and exclusion has not been sufficiently accounted for.
\end{abstract}

Keywords Poland $\cdot$ Refugees $\cdot$ Church $\cdot$ Racism $\cdot$ Islamophobia $\cdot$ Anti-Semitism

\section{Introduction}

'Closing doors is not the solution... We all have the duty of welcoming our brother who flees from war, hunger, or violence.' (Pope Francis, 2016)

Kasia Narkowicz

kasia.narkowicz@york.ac.uk

1 Department of Sociology, University of York, York, UK 
'Our acts are primarily about Christian love... Gospel not the Quran!'

(Jacek Międlar, far-right priest, 2015)

'I will be very clear. I do not see the possibility for migrants to come to Poland at this time.' (Beata Szydło, Prime Minister, 2016)

2015 was a significant year in Poland. The election of the right-wing political party Prawo $i$ Sprawiedliwość [Law and Justice] at the height of the refugee crisis sent a strong message about the political direction in which the country was heading. The incoming Eurosceptic right-wing government promoting Catholic patriotic values became the latest addition to the populist current in the region, ideologically following in the footsteps of Orban's Hungary (Buckley and Foy 2016). Hostility towards immigrants, particularly Muslims, was at the forefront of the 2015 political campaign in Poland. The intensification of xenophobic discourse in the country is being linked to the mainstreaming of ideas about the 'Islamisation' of Europe and, consequently, of Poland (Pędziwiatr 2017). A key current within this is the role of the ongoing project of re-Christianisation of Poland, initially promoted by the late Polish Pope and now furthered by the current government in a more exclusive fundamentalist narrative that considers Muslims a threat to its vision of a Christian Poland. When quotas for accommodating refugees were proposed by the EU, the Platforma Obywatelska [Civic Platform party], then in power, agreed to receive migrants as part of the relocation scheme (Szczerbiak 2017). The Law and Justice party, then in opposition, gained support through its vehement opposition of the idea of EU quotas, suggesting that they undermined 'Poland's traditional values and national identity' (Szczerbiak 2017, p. 1). When Law and Justice later came to power, it refused to accept the refugees allocated through this EU quota system. While the EU relocation scheme may be critically scrutinised for being potentially unfair on Eastern nations (Bovens and Bartsch 2015), its rejection by the Law and Justice party was only partially attributed to posing too high a burden on the country and predominantly dismissed due to it being perceived as an unwelcome imposition from abroad (Rp.pl 2017) and a security risk (Cienski 2017).

The imagined threat of a Muslim terrorist arriving from Syria disguised as a refugee has dominated public discourse on refugees in Poland. The populist narrative, promoted by the Law and Justice party, sees the EU as well as the refugees as invaders. The EU has been depicted by them as a hegemon forcefully trying to push refugees through Polish borders and the Muslim refugees as invaders determined to wipe out Poland's European (Christian) civilisation (Kotras 2016). The common narrative on the right warns against repeating the mistakes of Western nations by accepting refugees (Szczerbiak 2017). However, in contrast to countries such as Germany or the UK, there are very few refugees that seem to want to come to Poland. In 2016, the numbers of applications for refugee status in Poland submitted by Syrians reached almost 300 people, double the numbers in the previous year. This is in stark contrast to the over 250,000 Syrian asylum applicants in Germany (Eurostat 2016). As such the threat of a 'Muslim invasion' is an imagined one that does not correspond to the Polish reality.

This paper argues that the Polish response to the so-called refugee crisis should be analysed as a subtext to the broader political changes in the country, whereby the figure of the Muslim terrorist disguised as a refugee has allowed the government to advance its nationalistic agenda aiming to exclude all that is considered 'foreign'. The aftermath of the refugee crisis showed a rise in xenophobic attitudes, including Islamophobia and anti-Semitism. Whilst this reflects an alarming escalation of hate in the country, an analysis of the events should take into consideration Poland's history of racial Othering and exclusion (Bilewicz and Krzeminski 2010). The paper opens by looking back at the history of ethnic and religious diversity in Poland and its 
gradual turn towards the exclusion of minorities. It then examines the differing responses to the refugee crisis of the Catholic Church, the State and civil society. It shows how the migration crisis has been used as a subtext to put forward a broader nationalistic agenda, one in which there is little space for any Otherness.

\section{A Diverse Past and the Gradual Turn Towards Exclusion}

Although Poland is now one of the most religiously and ethnically homogenous countries in Europe with around $90 \%$ of the population declaring themselves as Catholics (GUS 2014), historically the country has been much more diverse, being home to a significant Jewish and Muslim community. In contrast to mobilisations against the presence of religious and ethnic minorities in recent Polish history, historically the region has been celebrated for its progressive attitudes towards minorities tracing back to the sixteenth century liberal rule of the Jagieło dynasty (Antonowicz-Bauer 1984). In pre-war Poland, over 30\% of the population was comprised of ethnic minorities with significant numbers of Jews, Ukrainians, Armenians and Germans inhabiting what was then the Polish-Lithuanian Commonwealth and one of the most diverse countries in Europe (Davies 1981).

\section{Polish Jews, Anti-Semitism and Emigration}

The drastic change in the numbers of ethnic and religious minorities in the country can be partly explained by the shifting of the borders in Central and Eastern Europe and then by the World Wars, particularly the Second World War that greatly impacted Poland's Jewish population. However, Polish Jews began leaving Poland in large numbers before the First World War-between 1881 and 1914, over two million Jews emigrated from Poland, the majority (over $85 \%$ ) to the USA and the rest to South America, Canada, Palestine and South Africa (Polin Museum 2016). These migrations reflected a worsening economic climate for the Jewish population in the country, coupled with an increased hostility towards the minority (Sroka 2010). In the second national census conducted after the First World War in 1931, the Jewish population in Poland was around 10\% (GUS 1931). For those Jews that survived World War II and stayed in Poland, life was difficult because of the continuing anti-Semitism that accompanied Communist rule (Bilewicz and Krzeminski 2010; Bilewicz et al. 2013). The Communist authorities instructed all those Jews who emigrated, some to what was to become Israel and others to European countries where they had friends or relatives, to relinquish their Polish citizenship (Stola 2000). According to Bilewicz and Krzeminski (2010), the antiSemitism without Jews in post-Communist Poland was correlated with increased levels of deprivation among Poles in the years of transition, during which the figure of the Jew became a scapegoat. Whilst attitudes towards Jews in Poland have recently improved (CBOS 2015), anti-semitic sentiments have certainly not been eliminated. With the improving attitude towards the Jews, the new folk devil in the Polish public imagination is the Muslim (Pędziwiatr 2010).

\section{Polish Muslims and Rise of Islamophobia}

Similarly to Jews, Muslim minorities have lived in Poland for centuries. The first Muslim presence in what then was the Polish-Lithuanian state was of Tatar refugees in the fourteenth 
century (Chazbijewicz et al. 1997). Throughout the many years of Muslim presence in the region, there has been almost no recorded prejudice towards the community (Dziekan 2011). Prior to 2010, the discourse around Muslims as a 'threat' mainly focussed on reporting of events such as terrorist attacks in the USA and deaths of Polish soldiers during Western invasions of Iraq and Afghanistan (Pędziwiatr 2017). In 2010, the national debate around Muslims and Islam started shifting slowly when conflicts around the construction of two mosques in Warsaw erupted (Narkowicz and Pędziwiatr 2016). The mosque conflicts gave rise to a wave of unprecedented attacks on the few mosques that have served the Muslim communities in Poland for many years. In a sequence of unfortunate events, mosques across the country were targeted; the most prominent of these attacks was when a severed pig's head was thrown into the newly built Warsaw mosque shortly after its opening (Narkowicz 2014). This was also the first time during the country's long Islamic presence that the old Tartar mosques and their adjacent cemeteries have been vandalised, and the first time that there have been successful petitions against new mosque constructions. As these events unfolded, a simultaneous rise in physical and verbal attacks on minorities was also observed (Więcej 2016). This included people being beaten up, slapped in the face, spat at and sworn at in public spaces, and being asked to remove their headscarves at work (Nugdy Więcej 2016a). These tensions brewed in the public sphere, fuelled by the refugee crisis and the Polish elections of 2015, finally spilling over into the streets giving rise to significant public demonstrations against ethnic and religious Otherness, focusing on Muslim refugees. Poland's oldest anti-racist organisation Nigdy Więcej [Never Again] spoke of the 'biggest wave of hatred' in the country's recent history, reporting several incidents taking place every day (Nugdy Więcej 2017).

While the violent actions were predominantly instigated by far-right actors, the underlying hostility was increasingly reflected in the wider population. Islamophobic discourse corresponded with a notable increase in hostility towards minorities among the general population (CBOS 2016). Recent national and international surveys have consistently found that the majority of the Polish population hold negative attitudes towards Muslims (CBOS 2013; Stefaniak 2015; Zick et al. 2011). Only 4\% of Poles supported entry of refugees into their country in a scenario where the refugee would settle permanently in Poland, whilst a majority were either against welcoming refugees at all or agreed to accept them on a temporary basis only (CBOS 2016). Often being found to be more hostile to minorities than citizens in other European countries, Poland is a good example of the phenomenon of 'Islamophobia without Muslims' or 'platonic Islamophobia' (Włoch 2009; Górak-Sosnowska 2006) whereby the population has negative attitudes to the group despite there being almost no Muslim presence in the country. In a 2011 European survey, almost half of Poles were of the opinion that there are 'too many Muslims' in their country (Zick et al. 2011). Despite an estimated Muslim population of only 35 thousand in a country of 38 million people, less than $0.1 \%$ of the population (Perils of Perception 2016), Polish citizens overestimated more than any other population in Europe the number of Muslims in their country, believing that Muslims make up 7\% of their country's population (Narkowicz and Pędziwiatr 2017). The hostile attitudes and exaggerated perception of the size of the Muslim minority may in part be explained by the disproportionately frequent and high-profile negative media reporting about Muslims and Islam.

\section{Anti-refugee Attitudes}

Anti-refugee narratives have been exacerbated by some media outlets, particularly on the right, frequently portraying Muslim refugees through orientalised images of a Muslim invasion 
(Kotras 2017). For example, at the height of the refugee crisis in 2015, right-wing magazines wSieci and DoRzeczy ran stories with headlines such as 'They are coming' and 'They are invaders not refugees' (Pędziwiatr 2017). Following sexual assaults that allegedly took place during New Year's Eve in several European cities, in February 2016, the government's rightwing vessel wSieci gained widespread attention across Europe when it ran with a story called 'Islamski Gwałt na Europe' [Islamic Rape of Europe] portraying a white woman who was screaming while brown hands were ripping apart an EU flag draped around her body (Narkowicz 2016a). This echoed narratives of a threat to white women posed by 'dangerous brown men' (Bhattacharyya 2008). Even the more balanced media outlets in Poland emphasised the Otherness of the refugees with covers that read 'What do we do when they come' (Kotras 2017). Following Stuart Hall (1997), such practices of representation contribute to a production of knowledge about the Other, which reflect the rise in hostile public attitudes towards Muslims. Although these attitudes are unprecedented in Poland in relation to Muslims, they need to be analysed as a continuation of racial Othering that historically affected other groups, predominantly the Jews. Edward Said (1985) has noted that Islamophobia and anti-Semitism, particularly in the Christian context, stem from the same source. Scholars of both anti-Semitism and Islamophobia have echoed Said and argued that these prejudices need to be understood together (Kalmar and Ramadan 2016) not least because the anti-Muslim mobilisations of today frequently evoke anti-Semitism (Kalmar 2017), also in Poland. Therefore, this paper argues, the responses to the refugees should be analysed as part of a bigger process and - while significant in its own right - as also functioning as a subtext to a nationalistic Eurosceptic agenda. These discourses are encouraged by different actors across Polish society; right-wing Catholic media outlets, far-right groups, some priests as well as key politicians in both the ruling party and the opposition. The following section maps these different, and conflicting, responses to the refugees from the Catholic Church, the State and finally, from various civil society actors.

\section{Church Response}

'Our country has many times served as refuge for those who had to flee from persecution (...) This hospitality should be upheld and nurtured as part of the Christian sensibility and national tradition' (Letter signed by various Churches in Poland, June 2016)

'I often hear that I am a fascist priest. Nonsense! (...) Our acts are primarily about Christian love. (...) We need bravery and courage... but not from Allah and leftists, but from Jesus Christ! Gospel not Quran!' (Jacek Międlar, Priest, anti-refugee march, October 2015)

Perhaps on opposite ends of the debate, the two quotes above show complex positions present within the Catholic Church with regard to refugees. The first quote reflects an official stance taken by the Catholic Church authorities in response to the refugee crisis, however one that has been questioned for its mere theoretical position that reflects little on actual attitudes and even less on the actions of the Polish Church. The second quote reflects the most radical far-right stance within the Church, expressed here by a priest who has since resigned his priesthood but maintains an active public life as an activist. This stark contrast between the official prorefugee Church narrative and the much more hostile voice of an individual priest sheds light on 
a gap between the moral authority of the Church and the people within it, who seem more ideologically in line with the reactionary right-wing populist narrative espoused by the government (CBOS 2016).

\section{A Divided Church}

There are two key movements within the Polish Catholic Church: a smaller progressive movement of 'Open Catholicism' and the much bigger traditionalist wing. The first group comprises a minority within Polish Catholicism, yet one that has a long and respected legacy in Polish politics. It has historically engaged in critical debates with the secular left and still contributes to the public sphere through magazines such as Znak, Tygodnik Powszechny and Więź that resist a reactionary Catholicism in Poland (Romanowski 2012). While 'Open Catholicism' has historically attracted many figures from within the Catholic intelligentsia and beyond including former Pope John Paul II, priest Józef Tischner and Cardinal Stefan Wyszyński, it also has been critiqued as too liberal by sections of the Polish Catholic Church. For example, the priest and editor-in-chief of Tygodnik Powszechny Adam Boniecki was banned from public expression outside of the platform of his Catholic magazine because he engaged in a debate with an artist who burned a Bible on stage. Another prominent example is of priest Lemański, who was suspended from the priesthood after he frequently critiqued the Catholic Church for how it addressed issues like the sexual abuse of children and the persecution of Jews in Poland. He was eventually suspended for failure to comply with the teachings of the Church (Gąsior 2012). Disciplining actions by the Church hierarchy are also extended towards those within 'closed Catholicism', however seemingly more reluctantly.

This second group, often referred to as 'Closed Catholicism', is the much larger and more influential movement of reactionary traditionalist right-wing Catholicism that has more in common with the current government. It is predominantly embodied by the popular Catholic radio station Radio Maryja, created by Tadeusz Rydzyk, a priest and businessman who runs a media conglomerate that include newspaper Nasz Dziennik and television station TRWAM. They propagate a conservative form of religious nationalism with Radio Maryja airing daily prayers as well as shows that have been accused of political propaganda, anti-Semitism and racism (CBOS 2011). Priest Rydzyk, a figure hated by many, has also been accused of propagating racism. In 2009 during a religious conference in Brazil, priest Rydzyk ridiculed a black priest saying that he has not 'washed' (Fakt.pl 2009). He critiqued the investment made to build Polin - the museum of Polish Jews - while not investing in 'Polish history', thereby suggesting that he did not view the long history of Jewish presence and its persecutions as part of Polish history (Tvn24.pl 2007). The media outlets support the right-wing government, helping it to advance a religiously based national ideology that attract many, not least the attention of media and scholarship (Krzemiński 2017, Pędziwiatr 2010, Wysocka 2008). The Polish statistical institute estimated that in 2008 between 2 and $4 \%$ of the Polish population listened to Radio Maryja and in 2011, the number had shot up to 15\% (CBOS 2011). The listeners are often ridiculed and presented in the mainstream as stupid, sad and backwards. Scholars have suggested that dismissing a largely disadvantaged portion of the Polish population might have contributed to the steady growth of populism in the country (Krzemiński 2017).

These abovementioned divisions within the Church are significant in understanding the Church's position on refugees, as clergy are divided between those urging the Polish Catholic Church to follow the instructions of their Pope and those that align themselves with the rightwing government's rhetoric around Muslim refugees, invasion and fear of terrorism. 


\section{Pro-refugee Church}

Since the refugee crisis unfolded in 2015, the highest authority in the Catholic Church has consistently engaged with the issue, urging Catholic dioceses to welcome refugees:

'It is a commitment that involves everyone, without exception. Dioceses, parishes, institutes of consecrated life, associations and movements, as individual Christians we are called to welcome the brothers and sisters fleeing war, famine, violence and inhumane living conditions.' (Pope Francis 2016)

The Pope's actions in regard to the refugees contrast starkly with the policies of the Polish government. Only a few months after the Polish government decided to close its borders, the Pope spoke about accepting refugees. The Pope's stance gained added significance as his speech was held in Poland, during his visit to Kraków for the World Youth Day during the summer of 2016 (Allen 2016):

'Today the war in Syria has caused pain and suffering for so many people... We have no desire to conquer hatred with more hatred, violence with more violence, terror with more terror... Life nowadays tells us that it is much easier to concentrate on what divides us, what keeps us apart. People try to make us believe that being closed in on ourselves is the best way to keep safe from harm. Today, we adults need you to teach us how to live in diversity, in dialogue, to experience multiculturalism not as a threat but an opportunity. Have the courage to teach us that it is easier to build bridges than walls!' (Pope Francis, 2016)

The reactions within the Polish Catholic Church to Pope Francis' position on refugees varied significantly. The Polish Episcopal Conference, which responded officially to the Pope's appeal, wrote that the Catholic Church in Poland 'will do everything within her power to assist refugees'. But it also said that the Church cannot act alone and that the main responsibility rests on the secular authorities (TvpInfo 2015). Bishop Krzysztof Zadarko, who is the Church's chairman for matters relating to migration, has said that the Church is 'unequivocal' in relation to refugees, as it is guided by the Gospel that encourages assistance to those in need. Recognising the criticism of the Pope's stance on refugees, Zadarko emphasised the importance of the Pope's authority that many undermined:

'There is a wave of hatred streaming through the internet. The Pope is accused of betraying the Church, for extending a helping hand not towards Christians but Muslims. I trust the Pope. He extends help to those who are in an absolutely hopeless situation' (Bishop Zadarko, 2017)

In Poland, words of the Pope have been historically of great significance. John Paul II, who was Polish, occupied a significant place in the public consciousness of many Poles. And while Pope Francis is still considered a moral authority for the majority of the population (CBOS 2014), his message has not been embraced by all Catholics. Rather the stated support seems superficial, even among the clergy, and does not translate into action. A recent study conducted in Polish seminaries reflected what seems to be a wider trend of agreeing with the teachings of the Pope in theory yet not supporting the teachings' practical implications, especially in the context of welcoming refugees (Pędziwiatr 2018). Most of the future priests interviewed by Pędziwiatr preferred to accept Christian refugees rather than Muslims, a view in line 
with both the current right-wing government and the general Polish public opinion, but not the Pope (Pędziwiatr 2018).

\section{Anti-refugee Church}

The Pope's position on refugees, while repeated by many Church hierarchs, was overshadowed by the more reactionary nationalistic response. Public figures that identify with right-wing Catholicism, in line with the ruling PiS party, have commented on Pope Francis's pro-refugee stance and gestures as being 'wrong', showing 'signs of docility' and having potential effects for the security of the country (Pch24.pl 2015). In one example, a member of the nationalist group ONR that identifies as Catholic published a photo of the Pope with a beard calling him 'Imam Bergoglio' because of his open attitude towards refugees (Stop Nacjonalizmowi 2017).

Perhaps the most virulent and public critic of Islam and Muslims within the Catholic Church is a now former priest named Jacek Międlar, who until his resignation in 2016, delivered controversial sermons in churches that attracted large crowds of sympathisers (Gajek 2015). Hailed as the new face of Polish nationalism, he represents the most radical position within the Church, in line with far-right nationalistic sentiments (McLean 2015). During a speech at the 2015 March of Independence, an annual nationalistic event, Miedlar spoke about the Catholic identity of Poland and the importance of nationalism against 'leftist' influences. Specifically targeting Muslims, he said that Poland needs to defend itself against Islamic fundamentalism (Międlar 2015). While still a priest, Międlar organised a sermon in the city of Białystok to celebrate the anniversary of the birth of the radical nationalist camp ONR. After the sermon, the group held a march in the city that led to the city authorities urging all foreign students to stay inside their homes. During the march, activists shouted 'We don't want Islam, terrorists or Muslims /.../ and Zionists will hang from trees' (Więcej 2016). The Church authorities apologised for hosting the far-right organisation and distanced themselves from priest Miedlar, condemning the usage of the Church as a space for a nationalist far-right gathering. The officials said that the institution does not support nationalism and that the Church space should be used for 'preaching love to everyone' (Dziennik.pl 2016). Yet, when the self-proclaimed nationalist, anti-Semite, racist and homophobe priest initially started preaching from the pulpit, the Church was silent. One of the critiques of the Church in relation to the way it reacted to Międlar stressed a pattern where the Church hierarchy ignored the teachings of the Pope:

'As usual in the situation, where there is need for Christian courage and decency, they [Church] are silent. (...) The silence of the hierarchy towards the actions of priest Międlar, who is destroying the legacy of John Paul II is an accurate portrayal of the attitude of the Church authority towards the teachings of the Polish Pope'. (Makowski 2016:1)

The case of the far-right priest, his popularity and the way in which different figures within the Church responded to him, by either facilitating a space for him or by condemning and excluding him, reflects deeper tensions within the Polish Catholic Church. While it is Międlar who has received most attention and attracted crowds of sympathisers, there have been several other individual priests who have espoused similar views. For example, a priest wrote on his Facebook page that the 'Quran should be burned' and that any comparison of the Quran with 
the Bible is 'blasphemy' (Więcej 2016, p. 8). One priest in Białystok said of the far-right ONR group that 'patriotism is the love of all that is good and serves the wellbeing of the nation. ONR is a patriotic organisation' (Chołodowski 2016, p. 1).

\section{Political Church}

These events shed light on tensions within the Church and the extent of its willingness to distance itself from right-wing Catholic nationalism. Since the elections in 2015, more emphasis has been put on stressing a national Catholic identity in Poland promoted by the newly established right-wing government. This poses a challenge for the Church in Poland because the government, while preaching against refugees, also empowers the Church. Since most of those who are practicing Catholics currently also support the ruling Law and Justice Party (CBOS 2017), the Church has faced increasing pressure to better connect with its dwindling congregation and a way to ensure the Church is on par with its predominantly right-wing congregation is to maintain a close relationship with the government. While the Polish Catholic Church has always been a political Church, it has not always been on the side of the ruling power.

The Church has historically played a central political role in Poland, perhaps most prominently in the struggle for democratic rule in Poland during the Communist years. Solidarność [Solidarity Movement] had close ties to the Catholic Church throughout their struggle in opposition (Chełstowska 2008), and as such, the victory of Solidarność and democracy was also a victory for the Church. The Church's involvement in the transition from Communism to democracy was not regarded as a 'meddling' into politics (Kozłowska 2012); rather, the Church's active role in the shaping of Poland's new political agenda was understood as a continuation of its role in opposition to Communism (Chełstowska 2008). Since then, the Church has taken an active role in influencing the political agenda, though less with regard to human rights and democracy and more in relation to sexual politics, such as abortion, which has been heavily criticised by the feminist movement (Graff 2003). The Church's ability to influence the country's politics has strengthened with the election of the right-wing Law and Justice [PiS] in 2015. The ruling party established a closer relationship with the Church, in turn enabling the Church to gain political support behind some of its national priorities, such as banning abortion, which has been at the forefront of the Church's agenda since the fall of Communism (Fuszara 1993).

\section{State Response}

'I will be very clear. I don't see the possibility for migrants to come to Poland at this time' (2016, Beata Szydło, Prime Minister)

'Don't let anyone tell you that reluctance to refugees is a bad thing'

(Official ruling party Twitter account, 2017)

The election of the populist right-wing Law and Justice party in 2015 was of crucial importance to Poland's political response to the refugee crisis. The elections saw the change in power from Platforma Obywatelska [Civic platform] party to Prawo i Sprawiedliwość (Law and justice) party, reflecting a political shift from centre and conservative liberalism to 
conservative right-wing policies and, consequently, a change in approach towards refugees. Prior to the 2015 national elections, Poland's government pledged to accept 7000 refugees. This was part of the European relocation plan, which Poland initially agreed to but later retracted (Szczerbiak 2017).

\section{Refugees in the 2015 Elections}

Ahead of the 2015 elections, the Polish political debate was heavily influenced by rhetoric around the refugee crisis and consequently about Muslims and Islam. During the election campaign, all political parties talked about refugees, often instrumentalising the war in Syria for political gain. The party most recently in power, Platforma Obywatelska [Civic Platform], said that there would be tough negotiations with Europe regarding how many refugees to accept, Prawo i Sprawiedliwość (PiS) spoke about keeping Poland secure and used terrorism threats as justification for not welcoming refugees. A liberal party, Razem [Together], spoke about the responsibility to accept refugees and was as such more in line with Catholic teachings than the PiS party that identifies as a Catholic party. Kukiz'15, a right-wing political movement formed prior to the elections, warned that refugees are, in fact, terrorists. KorwinMikke, a radical-right politician and controversial EU parliamentarian that leads his own political party KORWiN, resisted what he saw as the West trying to push migrants into Poland, a sentiment that has been echoing in the political mainstream since the 2015 elections.

After the election victory of the right-wing Law and Justice party, a number of changes were introduced that indicated the direction in which the new government was heading in regard to ethnic and religious minorities. In 2016, when hate crimes against minorities were on the rise (Bujalski 2016), the Law and Justice resolved the Council Against Racial Discrimination and Xenophobia - the only government body that was working on tackling racial discrimination (Narkowicz 2016a, b). While the government started dismantling such support services for ethnic and religious minorities, it simultaneously started empowering the far-right civil society, thereby legitimating their presence in the public sphere. In one example, the government cut out sections on far-right ideology from educational material on hate crimes aimed at police forces (Pedziwiatr 2017).

\section{Racialising Refugees}

Poland's new Prime Minister Beata Szydło declared that Poland would not receive any migrants (Newsweek.pl 2016). The decision was taken shortly after the 2016 Brussels terrorist attacks and the justification was the fear of a similar threat if Muslims were to come to Poland. The security arguments were frequently weaved in with more openly racialised comments about refugees. In what was hailed a controversial statement reminiscent of Nazi rhetoric, the leader of the Law and Justice party Jarosław Kaczyński said that refugees could bring in parasites to Poland (Rettman 2015). Although more prominent on the right, politicians within the liberal mainstream political party also expressed racist and Islamophobic views in the height of the crisis. One such candidate, Katarzyna Bielańska from the Platforma Obywatelska [Civic Platform] - in power between 2007 to 2015 - ran a campaign that caused a public outcry. Her election poster compared people of colour to a burger bun and read 'Yes to black burgers, no to refugees.' (KrkNews 2015). Challenged by colleagues in her own, centre-liberal party, she responded that her campaign was not racist, yet admitted that the colour of the burger bun in her campaign did reflect the skin colour of refugees: 
The black colour of the burger bun is linked to the skin colour of refugees, which is darker than the skin colour of a Polish person (...) There is absolutely nothing racist about it, because I am not a racist myself. I am merely saying that we should first feed our own citizens, and only then welcome people from outside. (KrkNews 2015)

Some key political actors went as far as to join in the anti-refugee demonstrations organised across Poland in 2015 and 2016. The politicians that joined demonstrations against refugees organised across Poland in 2015 included Janusz Korwin-Mikke, the European Parliament member who is also known for his sexist and xenophobic views, and a former right-wing politician Robert Winnicki (Więcej 2016).

\section{Muslims Not Welcome Here}

In official State rhetoric, Polish government officials targeted Muslims in particular, linking them to terrorism. The spokesperson of the current right-wing government, Elżbieta Witek, justified the near-refusal stance by equating refugees with a security threat: 'The number of refugees is currently so big that no one can control it and we have said repeatedly that we cannot let the enemy into our home' (Rp.pl 2017). Her discourse still maintained reference to her Christian faith, when she said that 'a good Christian is one who helps, not necessarily by accepting refugees' (Cienski 2017). To her, the main issue with letting refugees and migrants in to Poland was that most of them were Muslims and 'the numbers of Muslims and the crimes committed by illegal immigrants is growing, so our political agenda is to help people in the place of conflict' (Rp.pl 2017). The Polish government showed more enthusiasm towards accepting the more desirable Christian refugees, however. An influential anti-Muslim organisation, the Estera Foundation, pledged to welcome around 2000 Syrian Christians (Pędziwiatr 2015). Following collaboration between the Polish state and the Estera Foundation, a couple of hundred Christians from Syria came to find refuge in Poland. While the plight of Christian refugees was emphasised, the Muslim refugees were banned.

The Muslim refugees, especially when proposed as part of a quote system by the EU, were seen by the political elites as a double imposition. The refugee was frequently constructed as an invader and threat to the Polish nation and when considered pushed in by the EU, the refugee also symbolised unwanted foreign interference. In a broader political shift towards nationalism, the populist Law and Justice party introduced several changes to the political system that polarised the nation (Korolczuk 2017). As Korolczuk (2017, p. 98) argues, 'street protests became normalized as a mean of communication between the citizens and power holders'. This is reflected in the mushrooming of civil society initiatives post-2015 elections.

\section{Civil Society Response}

The thesis about weak civil society in post-Communist states (Howard 2002) has been nuanced in recent years by scholars who call for a rethinking of the ways in which postsocialist civil societies have been conceptualised in predominantly Western scholarship (Jacobsson and Korolczuk 2017). Indeed, it is outside of formal institutions that much of the mobilisation for and against refugees has taken place. The cartography of initiatives that has sprung up from the grassroots since 2015 and the number of demonstrations both against and for the government, and against and for refugees, evidence a high level of activism taking place in Poland, on both 
sides of the debate. These street protests, while formulated in response to the refugee crisis, have to be understood as part of a wider phenomenon of growing political divisions in the Polish society, particularly since 2015 , that result in mass mobilisation from across the political spectrum (Korolczuk 2017).

\section{Anti-refugee Mobilisation}

The election of the conservative Law and Justice party gave legitimacy to right-wing nationalists and strengthened them in their activism that includes frequent attacks on minorities. Behind these incidents are groups and individuals often associated with far-right nationalist groups including the ONR [National-Radical Camp], Ruch Narodowy [National Movement] and more politically mainstream anti-Muslim groups such as SIOE [Stop Islamisation of Europe] and Polska Liga Obrony [Polish Defence League] to more liberal groups such as the secularist Europa Przyszłości [Europe of the Future] that have been central in legitimising Islamophobia outside of right-wing circles.

In the aftermath of the refugee crisis, several anti-refugee demonstrations were organised across Poland. During these demonstrations, minority groups including Muslims, Jews and Romans were targeted (Narkowicz 2016a, b). The content of these demonstrations reveals that while Muslim refugees are the immediate target, anti-Semitic discourses are frequently drawn upon in these public events. During an anti-Muslim demonstration organised by the far-right National Radical Camp, one participant set fire to an effigy of an Orthodox Jew who was holding an EU flag. The organisers argued that the effigy was of George Soros who is 'responsible for the Islamisation of Poland' and - betraying an old anti-Semitic trope - said that Jews occupy the highest positions of power in post-Communist Poland (Rybak 2017, p. 1). After another anti-refugee demonstration, a member of the far-right group ONR (National Radical Camp) was investigated for hate speech when she warned about white Europe becoming extinct and spoke about Muslims as rapists and Jews as imperialists who dominate Europe. She never got sentenced and the case was dropped, signalling a lack of priority by the officials to combat growing racism in the country (Harkukowicz 2017). During one antirefugee demonstration in Warsaw, racist slogans were shouted that included 'Poland for Poles', 'Islam - death of white Europe' and 'The whole of Poland shouts with us, kill Islam with machetes' (Nigdy Więcej 2016). During a football match in Gdańsk, football fans held antiMuslim banners during a game, causing their club to face penalties (Więcej 2016). In the midst of online discussions around refugees coming to Poland, some commenters referred to Auschwitz - the concentration camp located in Poland - as an 'ideal hotel' for refugees and called for the gas chambers to be re-opened (Wieliński 2015). These events symbolise issues that are at the core of the Polish anti-refugee politics that unveil a continuation of old racial exclusions. While Islamophobia has been analysed as a 'new anti-Semitism', anti-Semitism in Poland has returned almost as a 'zombie rising from the grave' (Kalmar 2017, p. 1).

\section{Pro-refugee Mobilisation}

The main resistance to growing racist attitudes and violence in Poland also occurs at the grassroots level where a visible response from within the Polish civil society to the recent shift to the right has been observed. This mobilisation is partly a consequence of a wider political climate in which citizens have felt that institutions are failing them and have, as result, taken to the streets in protest to a range of government policies as part of 'resistance against an 
oppressive state' (Korolczuk 2016, pp. 91). Lacking support within the political mainstream, the resistance has increasingly formed broad alliances across the Polish civil society. Prorefugee, anti-racist, feminist, left-wing and LGBTQ groups have joined together in various initiatives in recent years in what has become a resistance to what is perceived as a climate of hate towards not only ethnic and religious minorities, but to all forms of Otherness.

The Muslim community in Poland has been active too-despite lacking in capital to mount adequate response. The recently constructed, and much resisted, mosque in Warsaw has since its opening hosted several Open Days and various events, inviting non-Muslims to come and see the mosque and learn about Islam and its followers (Narkowicz and Pędziwiatr 2016). A powerful, if small, group of Muslim women based in Warsaw have since the mosque controversy been at the forefront of the resistance struggle against Islamophobia. The group, calling themselves Alejkumki, organise both within and without. Within the small friends' group, they meet and share ideas, experiences and teachings in a safe environment. Outside, they have gone out on to the Polish streets in the height of the anti-mosque protests, handing out roses in an act promoting love and peace, calling the initiative Róże Miłości [Love Roses]. Some Polish Muslims have participated in various media debates, becoming spokespeople for the diverse community of Poland who do not often get their voices heard. Several members of the Muslim community in Poland have been collaborating with the broader resistance in efforts to monitor, challenge and change the narrative on Islam in Poland. But they are too few to challenge what has become a dominant narrative about refugees in the country, caricatured in the monstrous figure of a terrorist (see Puar and Rai 2002) - a highly racialised representation of the Muslim that echoes earlier portrayals of Others as threats to the Polish nation.

While significant and alarming in their own right, these mobilisations, for and against refugees, also serve as subtext for a larger political shift in Poland, one that seeks to exclude 'invaders'. Within these nationalistic narratives, Muslims are not the only group targeted. The presence of anti-Semitism, particularly noticed among the far-right civil society, betrays a past of racial exclusion that is not entirely reckoned with and, as such, has been readily mobilised.

\section{Conclusion}

This paper mapped the aftermath of the 2015 refugee crisis in Poland, focussing on the responses of the Catholic Church, the State as well as Polish civil society. The refugee crisis has intensified divisions in an already fractured political landscape, one in which the rightwing populist government ignored instructions from both the EU and the Vatican. Since the election in 2015, the official government position has become increasingly hostile towards immigrants - particularly expressed through the closing of borders to Muslim refugees. Rightwing media closely aligned with the current government has frequently run with cover stories portraying Muslims as invaders, rapists and murderers.

The crisis has also unveiled the conflicted position of the Catholic Church, sandwiched between the authority of the Holy See and the right-wing Polish government. As depicted in the quotes opening this paper, the Polish Catholic Church has found itself somewhere between the contrasting stances of a pro-refugee Pope and a 'fascist' priest. When its supporters, and preachers, engaged in racist discourse that actively went against the teachings of the faith and instructions of the Pope, the Church found itself in a difficult position. Whilst the words of the Pope were embraced by the official Church authority, they were either received with tempered enthusiasm, ignored or, in some cases, completely rejected by sections of the Catholic 
community. Despite the fact that the Vatican guides the Church morally and provides its ultimate authority, on the ground, the Polish Catholic Church is supported by a reactionary nationalist movement and given significant power to influence the government on key issues that are at the core of its agenda, such as abortion. Consequently, when the encouraging words towards refugees of Pope Francis clashed with those of the government, it became obvious that in the current reality, Pope Francis is an authority on paper with little influence on the ground. Consequently, the official stance of the Polish Church, despite embracing pro-refugee messages, did not translate into action.

The figure of the Muslim as the ultimate Other has mobilised two diverging trends in the civil society. The 2015 elections empowered the extreme fringe groups on the right. This was seen through the several anti-refugee and anti-Muslim demonstrations held across Poland, attracting large crowds of Poles whose attitudes have grown increasingly hostile to refugees in general and Muslims in particular. As the government and the Church have facilitated spaces for the strengthening and legitimisation of the far-right movement, this has provoked a strong response from other elements within civil society to resist this shift resulting in increased levels of solidarity politics across difference. The more the Polish borders shrank to ensure no Others slip through, the more civil society activism mushroomed across Poland unveiling divisions within and between key public institutions that ran deeper than disagreement over whether to welcome refugees.

The refugee crisis and the domestic escalation of racist attitudes in its response have played into the current nationalist political climate of Poland, one that is hostile to any imposition from abroad. In this wider context, civil society became increasingly divided between those who felt empowered by the conservative Catholic agenda and those who felt that the government undermined the country's democratic values. Within this, the figure of the refugee became a symbol of the wider conflict in which the refugee crisis functioned as subtext. As the anti-refugee discourses has revealed, it is not only Muslims, but also Jews, that are targeted in what seems to be a revival of anti-Semitism. An understanding of the recent escalation in antirefugee attitudes in the country needs to be analysed as a continuation, rather than an entirely new phenomenon, one that is being furthered as part of a nationalist project.

Open Access This article is distributed under the terms of the Creative Commons Attribution 4.0 International License (http://creativecommons.org/licenses/by/4.0/), which permits unrestricted use, distribution, and reproduction in any medium, provided you give appropriate credit to the original author(s) and the source, provide a link to the Creative Commons license, and indicate if changes were made.

\section{References}

Allen, J. L.. (2016). Day one for Pope Francis in Poland augurs hidden drama. Crux Retrieved from https:/cruxnow.com/analysis/2016/07/26/day-one-pope-francis-poland-augurs-hidden-drama/

Antonowicz-Bauer, L. (1984). The Tatars in Poland. Journal Institute of Muslim Minority Affairs, 5(2), 345-359.

Bhattacharyya, G. (2008). Dangerous brown men: exploiting sex, violence and feminism in the 'war on terror'. London: Zed Books Ltd..

Bilewicz, M., \& Krzeminski, I. (2010). Anti-semitism in Poland and Ukraine: the belief in Jewish control as a mechanism of scapegoating. IJCV, 4(2), 234-243.

Bilewicz, M., Winiewski, M., Kofta, M., \& Wójcik, A. (2013). Harmful ideas, the structure and consequences of anti-Semitic beliefs in Poland. Pol Psychol, 34(6), 1-18.

Bovens, L., \& Bartsch, A. (2015). Why the refugee quota system is unfair on poorer eastern and southern EU states. LSE Blogs. Retrieved from http://blogs.lse.ac.uk/europpblog/2015/10/01/why-the-refugee-quotasystem-is-unfair-on-poorer-eastern-and-southern-eu-states/

Buckley, N., \& Foy, H.. (2016). Poland's new government finds a model in Orban's Hungary. Financial Times, Retrieved from https://www.ft.com/content/0a3c7d44-b48e-11e5-8358-9a82b43f6b2f?mhq5j=e1 
Bujalski, S.. (2016). Polska walczy z obcymi. Rośnie liczba ataków rasistowskich i ksenofobicznych. Gazeta Wyborcza, 16 September 2016. Retrieved from http://wyborcza.pl/1,75398,20699634,polska-walczy-zobcymi-rosnie-liczba-atakow-rasistowskich-i.html

CBOS. (2011). Dwadzieścia Lat Radia Maryja. Centrum Badania Opinii Społecznej. BS/168/2011. Warszawa.

CBOS. (2013). Stosunek Polaków do Innych Narodów. Centrum Badania Opinii Społecznej. BS/12/2013. Warszawa.

CBOS (2014). Pontyfikat Papieża Franciszka w opiniach Polaków. Warszawa: Centrum Badania Opinii Społecznej

CBOS. (2015). Postrzeganie Żydów i Stosunków Polsko-Żydowskich. Centrum Badania Opinii Spotecznej. (112). Warszawa.

CBOS. (2016). Stosunek Polaków do przyjmowania uchodźców. (12). Centrum Badania Opinii Społecznej, Warszawa.

Chazbijewicz, S., Bohdanowicz, L., \& Tyszkiewicz, J. (1997). Tatarzy Muzułmanie w Polsce. Gdańsk: Niezależne Wydawnictwo.

Chełstowska, A. (2008). Aborcja I Ruch pro-choice W Polsce. Antropologiczne Badania W Latach 2006-2008. Warszawa: Uniwersytet Warszawski.

Chołodowski, M.. (2016). ONR przytulony do Kościoła. Gazety Wyborcza. Retrieved from http://wyborcza.pl/1 ,75398,21093057,onr-przytulony-do-kosciola.html

Cienski, J. (2017). Why Poland doesn't want refugees. Politico. Retrieved from http://www.politico. eu/article/politics-nationalism-and-religion-explain-why-poland-doesnt-want-refugees/

Davies, N. (1981). God's playground. A history of Poland, Vol. 1: the origins to 1795, Vol. 2: 1795 to the present. Oxford: Oxford University Press.

Dziekan, M. M. (2011). History and culture of Polish Tatars. In Górak-Sosnowska (Ed.), Muslims in Poland and Eastern Europe. Warsaw: Faculty of Oriental Studies University of Warsaw.

Dziennik.pl (2016). Kuria odcina się od ONR. Swoją dezaprobatę wyraża także Episkopat. Dziennik.pl. Retrieved from http://wiadomosci.dziennik.pl/wydarzenia/artykuly/518489,kuria-przeprasza-za-onr-wkatedrze-kosciol-bialostocki-jest-apartyjny-i-jest-mu-obcy-nacjonalizm.html

Eurostat. (2016). Five main citizenships of (non-EU) asylum applicants 2016, Eurostat. Retrieved from http://ec.europa.eu/eurostat/statistics-explained/index.php/File:Five_main_citizenships_of_(non-EU)_ asylum applicants, 2016 (number of first time applicants, rounded figures) YB17.png

Fakt.pl. (2009). Przepraszają za rasizm Rydzyka. [ōnline] Available at: http://www.fakt. pl/wydarzenia/swiat/przepraszaja-za-rasizm-rydzyka/52s9pkl [Accessed 18 May 2018].

Fuszara, M. (1993). Abortion and the formation of the public sphere in Poland. In N. Funk \& M. Mueller (Eds.), Gender politics and postcommunism: reflections from Eastern Europe and former Soviet Union. London: Routledge.

Gajek, M.. (2015). Ks. Andrzej Luter o księdzu-narodowcu: To pseudochrześcijaństwo. Newsweek. Retrieved from http:/www.newsweek.pl/polska/ksiadz-jacek-miedlar-narodowiec-z-wroclawia-onr-,artykuly,371967,1. $\mathrm{html}$

Gąsior, M.. (2012). Bronił Nergala, dostał zakaz nauczania religii. Biskup ucisza naszego księdza blogera. NaTemat.pl. Retrieved from http://natemat.pl/6835,bronil-nergala-dostal-zakaz-nauczania-religii-biskupucisza-naszego-ksiedza-blogera

Górak-Sosnowska, K. (2006). Wizerunek islamu w Polsce na przykładzie podręczników szkolnych. In K. GórakSosnowska, K. Pędziwiatr, \& P. Kubicki (Eds.), Islam i obywatelskość w Europie. Elipa: Warszawa.

Graff, A. (2003). Lost between the waves? The paradoxes of feminist chronology and activism in contemporary Poland. Journal of International Women's Studies, 4(2), 100-116.

GUS. (1931). Drugi Powszechny Spis Ludności z. Dn. 9.Xii 1931 R. Warszawa: Biblioteka Głównego Urzędu Statystycznego.

GUS. (2014). Wyznania religijne. Stowarzyszenia narodowościowe i etniczne w Polsce 2009-2011. Warszawa: Główny Urząd Statystyczny.

Hall, S. (1997). Representation: cultural representations and signifying practices. London: Sage.

Harłukowicz, J.. (2017). Justyna Helcyk z ONR jest nietykalna? Prokuratura umorzyła śledztwo. Wyborcza Wrocław. Retrieved from http://wroclaw.wyborcza.pl/wroclaw/7,35771,21777064, brunatna-szefowanietykalna.html

Howard, M. M. (2002). The weakness of postcommunist civil society. J Democr, 13(1), 157-169.

Jacobsson, K., \& Korolczuk, E. (2017). Civil society revisited. Lessons from Poland. New York: Berghahn Books.

Kalmar, I.. (2017). Is antisemitism the new islamophobia? The Wellington review. Retrieved from https://wellingtonreview.wordpress.com/2017/09/09/is-antisemitism-the-new-islamophobia/

Kalmar, I., \& Ramadan, T. (2016). Antisemitism and islamophobia. In Y. Meri (Ed.), Handbook of MuslimJewish relations. New York and London: Routledge. 
Korolczuk, Elżbieta. 2016. Explaining mass protests against abortion ban in Poland: the power of connective action, Zoon Politikon Journal, 2016(7), 91-113

Korolczuk, E.. (2017) Explaining mass protests against abortion ban in Poland: the power of connective action. Zoon Politikon.

Kotras, M.. (2016). Dyskurs o imigrantach. Strategie argumentacyjne w polskich tygodnikach opinii. Folia Sociologica, (59), 59-80. https://doi.org/10.18778/0208-600X.59.04

Kozłowska, D.. (2012). In Dubio Pro Reo. Znak, 686-697. Retrieved from http://www.miesiecznik.znak.com. $\mathrm{pl} / 5365 /$ in-dubio-pro-reo.

KrkNews. (2015). Uchodźcy czy... burgery? KrKNews.pl. Retrieved from http://krknews.pl/uchodzcy-czyburgery-kandydatka-po-zaskakuje/

Krzemiński, I. (2017). Radio Maryja and Fr. Rydzyk as a creator of the national-Catholic ideology. In: Religion, politics, and values in Poland (pp. 85-112). Palgrave Macmillan US.

Makowski, J.. (2016). Ks. Jacek Międlar: Dumny antysemita w koloratce. A Kościół milczy. Newsweek. Retrieved from http://www.newsweek.pl/opinie/ks-jacek-miedlar-wpisy-twitter-joanna-scheuring-wielgus,artykuly,395406,1.html

McLean, D. C.. (2015). The priest who is the new face of Polish nationalism. The Catholic world report. Retrieved from http://www.catholicworldreport.com/Blog/4432/The_priest_who_is_the_new_face_of Polish_nationalism.aspx

Międlar, J.. (2015). Marsz Niepodległości 2015 - przemówienie - ks. Jacek Międlar. YouTube. Retrieved from https://www.youtube.com/watch?v=9MdZKOZwg9I\&ab channel=JohnMay

Narkowicz, K. (2014). The rise of Polish Islamophobia. Baltic Worlds, VII, 12(2-3), -13.

Narkowicz, K. (2016a) Re-emerging racisms: understanding hate in Poland. Discover Society, (33), Retrieved from http://discoversociety.org/2016/06/01/re-emerging-racisms-understanding-hate-in-poland/

Narkowicz, K.. (2016b). Czarny protest: how Polish women took to the streets. OpenDemocracy. Retrieved from https://www.opendemocracy.net/can-europe-make-it/kasia-narkowicz/czarny-protest-how-polishwomen-took-to-streets

Narkowicz, K., \& Pędziwiatr, K. (2016). From unproblematic to contentious: mosques in Poland. J Ethn Migr Stud, 43(3), 441-457.

Narkowicz, K \& Pędziwiatr, K. (2017) Why are Polish people so wrong about Muslims in their country?. OpenDemocracy Retrieved from https://www.opendemocracy.net/can-europe-make-it/kasia-narkowiczkonrad-pedziwiatr/why-are-polish-people-so-wrong-about-muslims-in

Newsweek.pl (2016) Polska nie przyjmie imigrantów. Szydło: Nie widzę takiej możliwości. Newsweek Polska. Retrieved from http://www.newsweek.pl/polska/polska-nie-przyjmie-imigrantow-beata-szydlo-wwywiadzie-dla-superstacji,artykuly,382568,1.html

Pch24.pl. (2015). Paweł Lisicki: papież myli się w sprawie imigrantów. Polonia Christiana. Retrieved from http://www.pch24.pl/pawel-lisicki-papiez-myli-sie-w-sprawie-imigrantow,38026,i.html\#ixzz4uG2VQnJ7.

Pedziwiatr, K. (2010). Muslims in the Polish media - the new folk devil? Arches Quarterly, 4(7), 89-95.

Pędziwiatr, K.. (2015). Kryzys uchodźczy i polskie lęki przed muzułmanami. Gazeta Wyborcza.

Pędziwiatr, K.. (2017). Islamophobia in Poland: National Report 2016. In: Enes Bayralki \& Farid Hafez, European Islamophobia report 2016, SETA. 411-443. Istanbul 2017.

Pędziwiatr, K.. (2018). The Catholic church in Poland on Muslims and Islam in the context of the migration crisis and ISIS terrorist attacks. Patterns of Prejudice (Special Issue, forthcoming).

Polin Museum. (2016). Main exhibition. Warsaw: Muzeum Polskich Żydów [Muzeum of Polish Jews].

Puar, J. K., \& Rai, A. (2002). Monster, terrorist, fag : the war on terrorism and the production of docile patriots. Social Text, 20(3), 117-148.

Rettman, A.. (2015). Poland: election talk on migrant 'protozoas' gets ugly. EU Observer. Retrieved from https://euobserver.com/political/130672

Romanowski, A.. (2012). Kościół, lewica, wojna. Znak (681). Retrieved from http://www.miesiecznik.znak. com.pl/6812011andrzej-romanowskikosciol-lewica-wojna/

Rp.pl (2017) Elżbieta Witek: Uchodźcy? Rząd nie zmieni zdania. Rzeczpospolita. Retrieved from http://www. rp.pl/Rzad-PiS/170518902-Elzbieta-Witek-Uchodzcy-Rzad-nie-zmieni-zdania.html\#ap-1

Rybak, M.. (2017). Jest wyrok za spalenia kukły Żyda na wrocławskim rynku. Przed sądem manifestacja narodowców. Newsweek.pl. Retrieved from http://www.newsweek.pl/polska/spoleczenstwo/dzis-wyrok-wsprawie-spalenia-kukly-zyda-przed-sadem-rozpoczela-sie-manifestacja,artykuly,408252,1.html

Said, E. W. (1985). Orientalism reconsidered. Race \& Class, 27(2), 1-15.

Sakowicz, E. (2011). Dialogue between the Catholic Church and Islam in Poland. In K. Górak-Sosnowska (Ed.), Muslims in Poland and Eastern Europe. Widening the European discourse on Islam. Warszawa: University of Warsaw.

Sroka, M.. (2010). Emigracja Zydow polskich w latach 1918-1939. Państwo i Spoleczeństwo. Rok X: nr.2. Kraków. 
Stefaniak, A. (2015). Postrzeganie muzutmanów w Polsce: Raport z badania sondażowego. Warszawa: Centrum Badania nad Uprzedzeniami.

Stola, D. (2000). Kampania antysyjonistyczna w Polsce 1967-1968. Instytut Studiów Politycznych (Polska Akademia Nauk): Warszawa.

Stop Nacjonalizmowi. (2017). Działacz ONR obraża papieża w Internecie. Niezależne Centrum Analiz. Ruchów Neofaszystowskich $i$ Ksenofobicznych. Retrieved from https://stopnacjonalizmowi. wordpress.com/2017/05/13/dzialacz-onr-obraza-papieza-w-internecie/

Szczerbiak, A.. (2017). How is the European migration crisis affecting Polish politics? Europp: European Politics and Policy blog. Retrieved from http://blogs.lse.ac.uk/europpblog/2017/07/06/european-migration-crisisaffecting-polish-politics/

Tvn24.pl. (2007). Publikujemy nagrania z wykładu o. Rydzyka. Tvn24. Retrieved from https://www.tvn24. pl/wiadomosci-z-kraju,3/publikujemy-nagrania-z-wykladu-o-rydzyka,27496.html

TvpInfo. (2015). Strona kościelna nie wyobraża sobie działania w tej materii na własną rękę. Episkopat ws. uchodźców. Tvp. Retrieved from https:/www.tvp.info/21547340/strona-koscielna-nie-wyobraza-sobiedzialania-w-tej-materii-na-wlasna-reke-episkopat-ws-uchodzcow

Więcej, N.. (2016). Katalog Wypadków - Brunatna Księga [Catalogue of incidents - the Brown book]. Nr22.

Więcej, N.. (2017). Anna Tatar z NIGDY WIĘCEJ o przestępstwach z nienawiści (w kontekście wypowiedzi ONR-u). Retrieved from https://vimeo.com/216788975

Wieliński, B.. (2015). Hejter polski: Auschwitz to idealny pensjonat dla Syryjczyków. Gazeta Wyborcza. Gazeta Wyborcza. Retrieved from http://wyborcza.pl/1,75968,18713459, hejter-polski-auschwitz-to-idealnypensjonat-dla-syryjczykow.html

Włoch, R. (2009). Islam in Poland: between ethnicity and universal umma. Int J Sociol, 39(3), 58-67.

Wysocka, O. (2008). Populizm i Radio Maryja. Miesięcznik Znak, 640(9), 61-74.

Zick, A., Küpper, B., \& Hövermann, A. (2011). Intolerance, prejudice and discrimination: a European report. Berlin: Friedrich-Ebert Stiftung. 